\title{
Investigation of Inorganic Phase Change Material for a Semi-Transparent Photovoltaic (STPV) Module
}

\author{
Alagar Karthick ${ }^{1}(0)$, Muthu Manokar Athikesavan ${ }^{2}{ }^{\oplus}$, Manoj Kumar Pasupathi ${ }^{3}{ }^{(1)}$, \\ Nallapaneni Manoj Kumar ${ }^{4} \mathbb{D}$, Shauhrat S. Chopra ${ }^{4}(\mathbb{D}$ and Aritra Ghosh 5,6,*D \\ 1 Department of Electrical and Electronics Engineering, KPR Institute of Engineering and Technology, Arasur, \\ Coimbatore 641407, Tamil Nadu, India; karthick.power@gmail.com \\ 2 Department of Mechanical Engineering, B.S. Abdur Rahman Crescent Institute of Science and Technology, \\ Chennai 600048, Tamil Nadu, India; a.muthumanokar@gmail.com \\ 3 Department of Mechanical Engineering, KPR Institute of Engineering and Technology, Arasur, \\ Coimbatore 641407, Tamil Nadu, India; pasupathimanojkumar@gmail.com \\ 4 School of Energy and Environment, City University of Hong Kong, Kowloon, Hong Kong; \\ nallapanenichow@gmail.com (N.M.K.); sschopra@cityu.edu.hk (S.S.C.) \\ 5 Environment and Sustainability Institute, University of Exeter, Cornwall TR10 9FE, UK \\ 6 College of Engineering, Mathematics and Physical Sciences, Renewable Energy, University of Exeter, \\ Cornwall TR10 9FE, UK \\ * Correspondence: a.ghosh@exeter.ac.uk
}

Received: 24 June 2020; Accepted: 10 July 2020; Published: 11 July 2020

\begin{abstract}
The semi-transparent photovoltaic (STPV) module is an emerging technology to harness the solar energy in the building. Nowadays, buildings are turning from energy consumers to energy producers due to the integration of the STPV module on the building envelopes and facades. In this research, the STPV module was integrated on the rooftop window of the experimental room at Kovilpatti $\left(9^{\circ} 10^{\prime} 0^{\prime \prime} \mathrm{N}, 77^{\circ} 52^{\prime} 0^{\prime \prime} \mathrm{E}\right)$, Tamil Nadu, India. The performance of the STPV modules varies with respect to the geographical location, incident solar radiation, and surface temperature of the module. The surface temperature of the STPV module was regulated by the introduction of the mixture of graphene oxide and sodium sulphate decahydrate $\left(\mathrm{Na}_{2} \mathrm{SO}_{4} \cdot 10 \mathrm{H}_{2} \mathrm{O}\right)$. The various concentration of the graphene oxide was mixed together with the $\mathrm{Na}_{2} \mathrm{SO}_{4} \cdot 10 \mathrm{H}_{2} \mathrm{O}$ to enhance the thermal conductivity. The thermal conductivity of the mixture 0.3 concentration was found to be optimum from the analysis. The instantaneous peak temperature of the semi-transparent photovoltaic phase change material (STPV-PCM) module was reduced to $9{ }^{\circ} \mathrm{C}$ during summer compared to the reference STPV. At the same time, the energy conversion efficiency was increased by up to $9.4 \%$ compared to the conventional STPV module. Due to the incorporation of the graphene oxide and $\mathrm{Na}_{2} \mathrm{SO}_{4} \cdot 10 \mathrm{H}_{2} \mathrm{O}$, the daily output power production of the STPV module was improved by $12.16 \%$.

Keywords: solar Photovoltaic (PV) module; building envelopes; solar facades; semi-transparent photovoltaic; inorganic phase change material; Building integrated photovoltaic (BIPV); Phase change material (PCM) for solar; graphene oxide; Glauber salt
\end{abstract}

\section{Introduction}

The depletion of fossil fuel leads to a search for renewable energy sources (RES) such as solar, wind, and fuel cells. Earlier, these energy sources were widely used for a large scale power generation sector. However, in recent years, due to the advancements seen in the distributed energy generation, the use of these RES has become much popular in various sectors, especially the integrated application in residential and other commercial buildings [1]. The RES integration into the building converts the building from energy consumer to energy producer [2]. A building can be considered a zero 
energy building (ZEB) if the required energy for the building is generated from RES. The ZEB is an emerging technology for harnessing solar energy in green buildings [3]. Among all the RES, the solar photovoltaic (PV) technology is more prominent. Comparing to other RES, to some extent, PV is an environmentally benevolent and cost-effective approach for producing energy, and overall, it can act as a reliable power source to the ZEB [4]. The integration of the PV module into building structures is termed as the building integrated photovoltaic (BIPV) system, and in some systems in which PV modules are just attached are termed as building attached or applied photovoltaic (BAPV) [5-8]. In the BIPV system, the integration of the BIPV modules are classified as the opaque, semi-transparent, and transparent system [9-11]. The BIPV system has many advantages like weather roofing, aesthetic look, power generation, and acoustic prevention [12]. The BIPV system converts the incident solar radiation light energy into electrical energy. The BIPV modules absorb only $25 \%$ of the incident solar radiation, and the remaining energy is converted into heat; some energy is reflected into the atmosphere due to the glare from the BIPV module surface [13]. The optimum operating condition of the BIPV modules is $25^{\circ} \mathrm{C}$. Due to the absorption of the solar radiation, the surface temperature of the BIPV module increases and also affects the energy conversion process and output power of the BIPV module [14]. Active and passive methods control the surface temperature of the PV module. The active method requires external sources to flow water or air by employing external power sources, which makes the overall system complex and costlier compared to the passive system $[15,16]$. The passive system adopts the phase change material (PCM) - a wicking material that does not require any external power. The incorporation of the PCM in the BIPV module does not affect the aesthetic look, in addition to the power generation, it also reduces the energy consumption in the heating or cooling load [17].

In literature, there exist studies related to PV or BIPV or photovoltaic thermal (PV/T) module performance with and without PCM. The numerical analysis was carried out to analyze the performance of the PV module with PCM and without PCM. The results were reported concerning the depth of the PCM incorporated as well as their effects. It was concluded that the PV surface temperature rises when the PCM gets solidified [18]. The water nanofluid with a mixture of $\mathrm{ZnO}$ is used as a PCM to cool the PV modules. It was reported that the electrical efficiency of the PV module was improved by $13 \%$ compared to the reference module. The exergy efficiency of the PV-PCM system was improved by $23 \%$ compared to the conventional system [19]. The building integrated photovoltaic phase change material (BIPV-PCM) system was fabricated and tested for the hot and humid climatic conditions in the region of the southern part of India. The Glauber salt PCM was investigated to enhance the performance of the system. It was reported that the electrical efficiency of the system was improved by up to $10 \%$, while the surface temperature was also reduced to $8^{\circ} \mathrm{C}$ compared to the conventional BIPV module [20]. The performance of the PV/T system was investigated, comprising of the three prototypes, which were heat pipes, incorporation of PCM, and reference system. It was concluded that the encapsulated PV/T PCM system had a higher efficiency of $36.7 \%$, while heat pipes PV/T and the reference system had an efficiency of $35.3 \%$ and $31.78 \%$, respectively [21]. The experimental study was conducted by integrating PCM and nanofluid into the PV/T system. It was reported that the electrical efficiency of the system was improved from $7.1 \%$ to $13.7 \%$ for the $0.17 \mathrm{~kg} / \mathrm{s}$ mass flow rate of water [22]. The graphene nanoparticles were used to enhance the performance of the paraffin incorporated PV system for the region of Saudi Arabia. It was concluded that the lesser concentration of the graphene nanoparticles increases the building's thermal energy gains. The performance test was conducted for the winter and summer seasons. It was reported that the electrical efficiency of the system was improved by $6.9 \%$ in winter and $25 \%$ in summer compared to the conventional system [23]. Graphene has played the role of the conductivity and the production of the photovoltaic cells, and a comprehensive review on the graphene-based solar cells can be seen in the studies in [24]. The combination of the graphene and $\mathrm{TiO}_{2}$ nanocomposite $\mathrm{PCM}$ can achieve three times higher efficiency than the incorporation of the $\mathrm{TiO}_{2}$ particles in the PV modules [25]. The investigation was carried out to enhance the performance of the thin-film solar module using the eutectic mixture of the calcium chloride hexahydrate and iron chloride 
hexahydrate. It was concluded that the Copper Indium diselenide module surface temperature was reduced to $9{ }^{\circ} \mathrm{C}$ [26]. The incorporation of the PCM and finned PCM in the PV module has enhanced the performance of the module. The PV-PCM system has improved the power production by $7 \%$ of daily production while $8 \%$ by finned PCM [27]. The feasibility of the incorporation of the PCM on the STPV module was analyzed and concluded that the incorporation of the PCM enhanced the power production and life span of the PV module. It is a cost-effective technique to cool the PV module [28]. The study was carried out to improve the performance of the BIPV system by employing the eutectic binary mixture of PCM which was developed using $\mathrm{Na}_{2} \mathrm{SO}_{4} \cdot 10 \mathrm{H}_{2} \mathrm{O}$ and $\mathrm{N}_{2} \mathrm{O}_{6} \mathrm{Zn} \cdot 6 \mathrm{H}_{2} \mathrm{O}$ to regulate the surface temperature of the BIPV module. It was concluded that the instantaneous surface temperature of the BIPV module was reduced to $12{ }^{\circ} \mathrm{C}$ [29]. The building integrated solar water heating system was investigated by incorporating the nano- $\mathrm{SiO}_{2}$ composite PCM for thermal management. The results reported that the nanocomposite PCM enhanced the system efficiency by $16.05 \%$ [30,31]. The paraffin wax was incorporated on the PV module to regulate the surface temperature. It was concluded that the electrical efficiency was improved by $6.34 \%$ [32].

According to the literature study, it is evident that the performance of the STPV module gets affected by the rise in temperature and incident solar radiation. The studies of [20,29] reported that Glauber salt has the potential to regulate the surface temperature of the STPV modules. Moreover, it was suggested that the increase in thermal conductivity could enhance the performance of the PCM. The inorganic PCM with the graphene oxide nanoparticles is needed for the hot and humid climatic conditions in the Southern part of India. The graphene oxide is capable to enhance the thermal conductivity of the inorganic PCM.

In this work, Glauber salt was mixed with graphene oxide nanoparticles to augment the thermal conductivity of the PCM. The developed PCM is incorporated in the STPV module and tested in the experimental room at the Kovilpatti region, Tamil Nadu, India, where the climatic condition is hot and humid.

\section{Materials and Methods}

\subsection{Materials}

The experimentation was carried out at the hot and humid climatic condition of the Kovilpatti region, Tamil Nadu, India. The schematic view of the STPV module is shown in Figure 1.

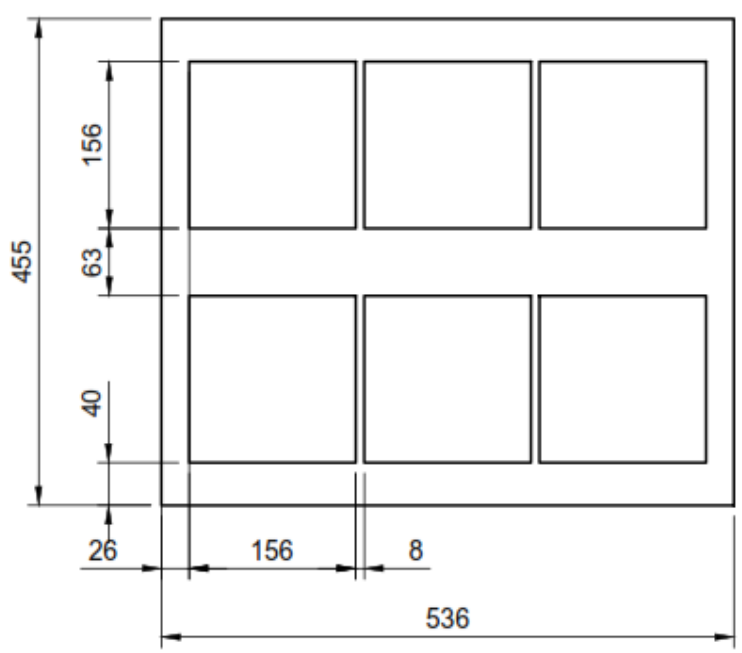

All Dimensions are in $\mathrm{mm}$

Figure 1. Schematic diagram of the semi-transparent photovoltaic (STPV) module. 
The selection of PCM is the major criterion in the passive PCM cooling, and for this reason, we analyzed the ambient temperatures at the experimental location. The PCM melting point was selected as $32{ }^{\circ} \mathrm{C}$ as per the observed range variation in ambient temperature, i.e., from $29{ }^{\circ} \mathrm{C}$ to $36^{\circ} \mathrm{C}$. The inorganic PCM was selected because its melting point is lower and has a higher latent heat. Hence, the inorganic Glauber salt $\left(\mathrm{Na}_{2} \mathrm{SO}_{4} \cdot 10 \mathrm{H}_{2} \mathrm{O}\right)$ with a melting temperature of $32^{\circ} \mathrm{C}$ was selected. The graphene oxide nanoparticle was mixed using a sonicator with $\mathrm{Na}_{2} \mathrm{SO}_{4} \cdot 10 \mathrm{H}_{2} \mathrm{O}$ to form a mixture that enhances the thermal conductivity. The sonification was carried out at $40 \mathrm{kHz}$ to prevent the sedimentation of the graphene oxide in the Glauber salt. The prepared nano-PCM was tested for the thermal conductivity to confirm the enhancement of thermal conductivity compared to that of PCM. The thermal conductivity and specific heat capacity of nano-PCM were assessed using a decagon make KD2-Pro type thermal analyzer. The stability and sedimentation of the nano-PCM dispersion were analyzed using the gravity sedimentation method [33]. The thermophysical properties of the Glauber salt and graphene oxide are listed in Table 1.

Table 1. Thermophysical properties of phase change material.

\begin{tabular}{cc}
\hline Particular & Specification \\
\hline Phase change material & Sodium sulphate decahydrate $\left(\mathrm{Na}_{2} \mathrm{SO}_{4} \cdot 10 \mathrm{H}_{2} \mathrm{O}\right)$ \\
Melting point/Freezing point & $32{ }^{\circ} \mathrm{C} / 4{ }^{\circ} \mathrm{C}$ \\
Density in solid/Liquid & $1458 \mathrm{~kg} / \mathrm{m}^{3} / 1485 \mathrm{~kg} / \mathrm{m}^{3}$ \\
Latent Heat & $251 \mathrm{~kJ} / \mathrm{kg}$ \\
Nanoparticles & Graphene oxide $\left(\mathrm{C}_{160} \mathrm{H}_{44} \mathrm{O}_{16}\right)$ \\
\hline
\end{tabular}

\subsection{Experimentation}

The experimentation was conducted during May 2019, placing the STPV at the rooftop window of the experimental room at National Engineering College, Kovilpatti, Tamil Nadu, India. The linear dimension of the experimental room length and height was $6 \mathrm{~m}$ and $3 \mathrm{~m}$, respectively. Two STPV modules were fabricated with a length, breadth, and width of $0.45 \mathrm{~m}, 0.70 \mathrm{~m}$, and $0.01 \mathrm{~m}$, respectively. Six series connected spaced type polycrystalline solar cells were sandwiched between the two-glass to form the STPV module. The other module (STPV-PCM) was fabricated by keeping the provision of the PCM incorporation at the rear side of every cell. The STPV system was monitored from 6:00 to 18:00. The voltage, current, and surface temperature parameters of both modules were measured every $60 \mathrm{~min}$. The various temperatures were measured to analyze the thermal performance. The specification of the STPV module is listed in Table 2.

Table 2. Technical specification of the STPV module with and without phase change material (PCM).

\begin{tabular}{ccc}
\hline Parameter & STPV & STPV-PCM \\
\hline Rated Power $W_{P}(\mathrm{~W})$ & 24 & 24 \\
Open circuit Voltage $V_{o c}(\mathrm{~V})$ & 3.786 & 3.786 \\
Short circuit Current $I_{s c}(\mathrm{~A})$ & 8.72 & 8.72 \\
Maximum voltage $V_{\max }(\mathrm{V})$ & 3.18 & 3.18 \\
Maximum current $I_{\max }(\mathrm{A})$ & 8.48 & 8.48 \\
Number of Solar cells $\left(N_{o s}\right)$ & 6 & 6 \\
PCM layer & - & Glauber salt and Graphene oxide \\
\hline
\end{tabular}

The STPV module with and without PCM is shown in the figure photographic view of the STPV, and the front and rearview of the STPV-PCM systems are shown in Figures 2 and 3, respectively. The experimental room was fabricated to test the STPV module by placing them on the rooftop window as shown in Figure 4. The instrument used for the analysis is presented in Table 3. 


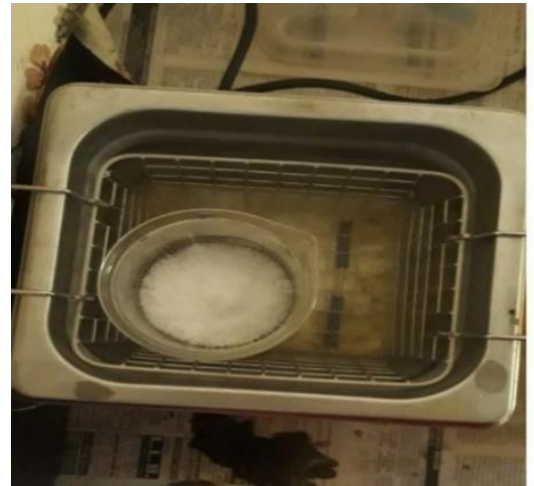

(a)

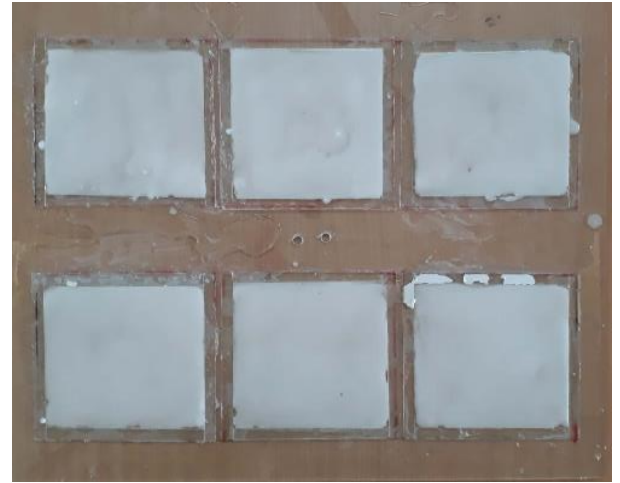

(b)

Figure 2. Preparation set up: (a) Preparation of nano-inorganic phase change material using a sonicator; (b) encapsulation of PCM in the STPV module.

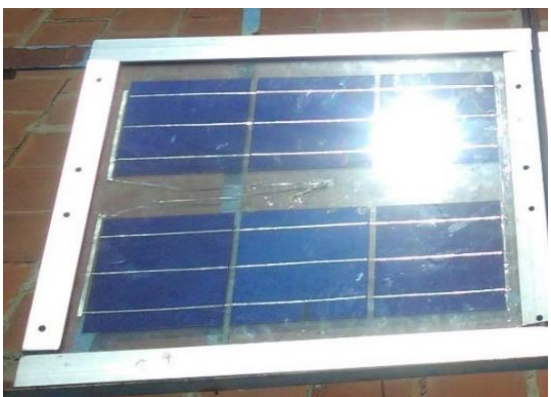

(a)

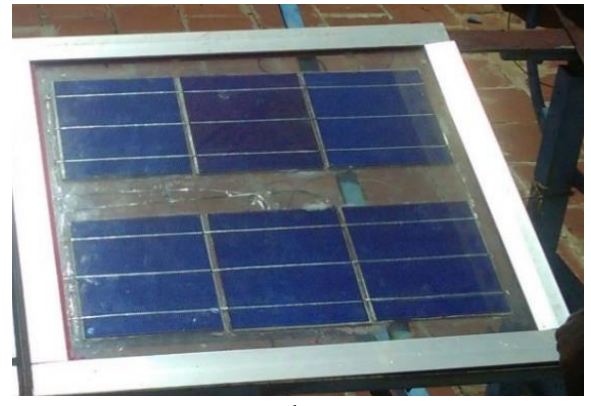

(b)

Figure 3. Photographic view: (a) STPV module without PCM; (b) STPV module with PCM.

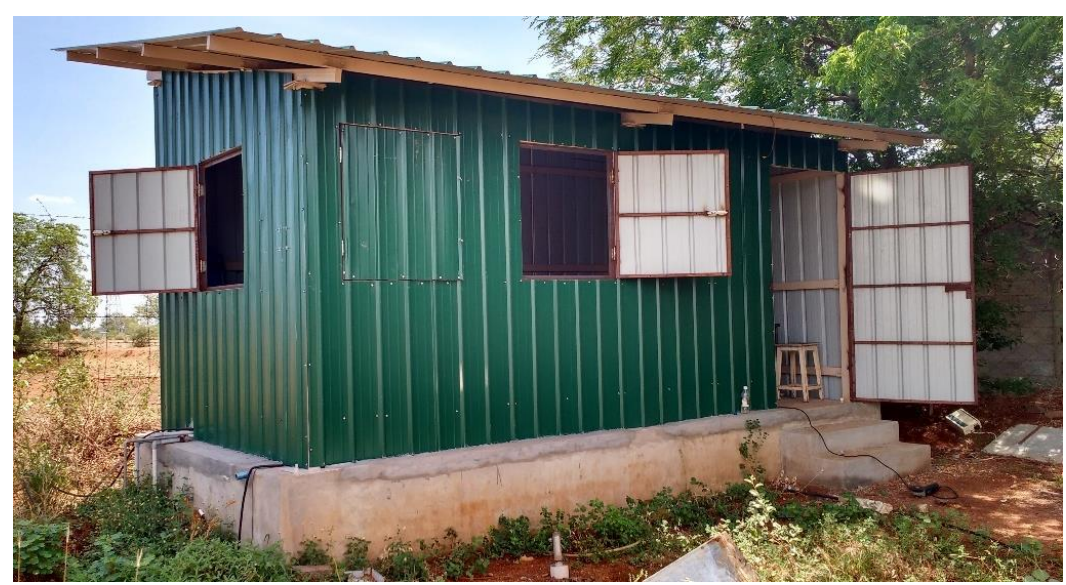

Figure 4. Experimental room to test the STPV modules.

Table 3. Details of instrument specification.

\begin{tabular}{ccc}
\hline Instrument & Range & Accuracy \\
\hline Voltmeter (Meco make) & $30 \mathrm{~V}$ & $\pm 1 \mathrm{~V}$ \\
Ammeter (Meco make) & $0-10 \mathrm{~A}$ & $\pm 0.1 \mathrm{~A}$ \\
Electrical Rheostat load & $40-\mathrm{ohm}, 2.5 \mathrm{~A}$ & $\pm 0.1 \%$ \\
K-type Thermocouple & $220{ }^{\circ} \mathrm{C}$ & $\pm 1{ }^{\circ} \mathrm{C}$ \\
Selec make temperature indicator & $0-500{ }^{\circ} \mathrm{C}$ & $\pm 1{ }^{\circ} \mathrm{C}$ \\
Pyranometer & $0-2000 \mathrm{~W} / \mathrm{m}^{2}$ & $\pm 1 \mathrm{~W} / \mathrm{m}^{2}$ \\
\hline
\end{tabular}




\section{Results and Discussion}

The performance of the STPV module was analyzed by integrating it on the building roof. The various parameters were analyzed, such as temperature, voltage, and current of the STPV module. To regulate the surface temperature of the STPV module, Glauber salt with the nanocomposite of graphene oxide was added. The addition of graphene oxide into Glauber salt enhanced the thermal conductivity of the salt. The various concentrations $(0.1,0.2,0.3$, and 0.4$)$ of the graphene oxide was mixed together. The thermal conductivity of the Glauber salt mixture was measured. In this mixed proportion, $0.3 \%$ of the concentration mixture was found to be the optimum in the enhanced thermal conductivity. The thermal conductivity of the mixture without adding the nanocomposite PCM was $0.51 \mathrm{~W} / \mathrm{mK}$. The addition of the concentration mixture and the enhancement is shown in Figure 5 . The increase in the concentration of the nanoparticles above $0.3 \%$ was found to be not suitable in the thermal conductivity as well as the sedimentation, which was observed in thermal cycling. The thermal conductivity of the material reached a maximum of $0.94 \mathrm{~W} / \mathrm{mK}$ for the concentration of $0.3 \%$ of the weight, while the minimum was $0.75 \mathrm{~W} / \mathrm{mK}$. The Differential scanning calorimetry curve for the sodium sulphate decahydrate is shown in the Figure 6.

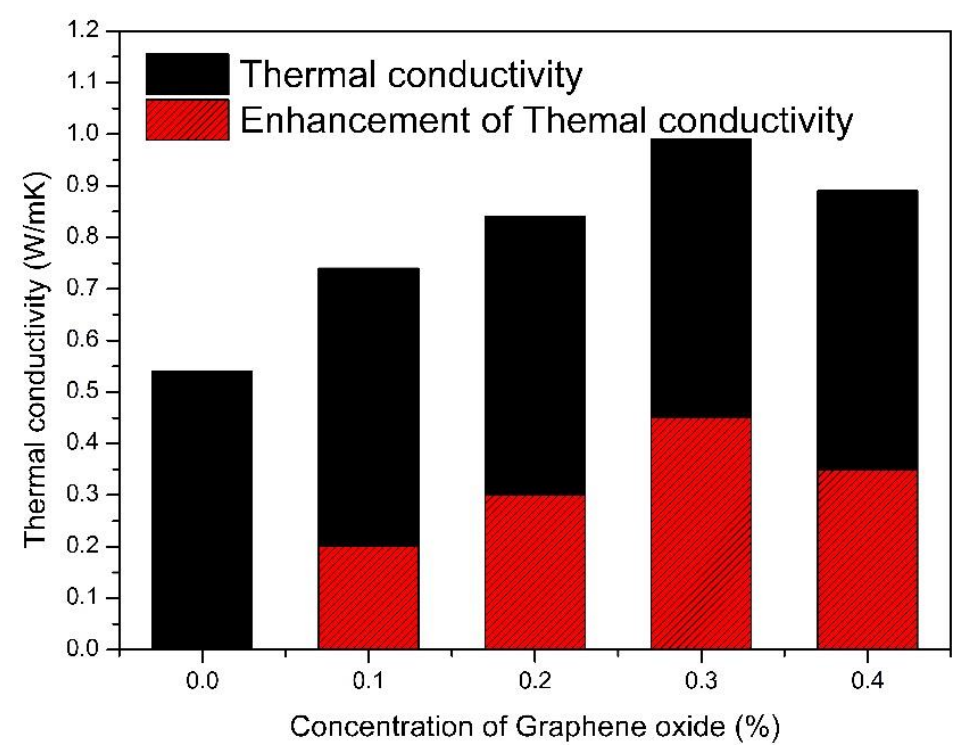

Figure 5. Concentration of graphene oxide and thermal conductivity of Glauber salt.

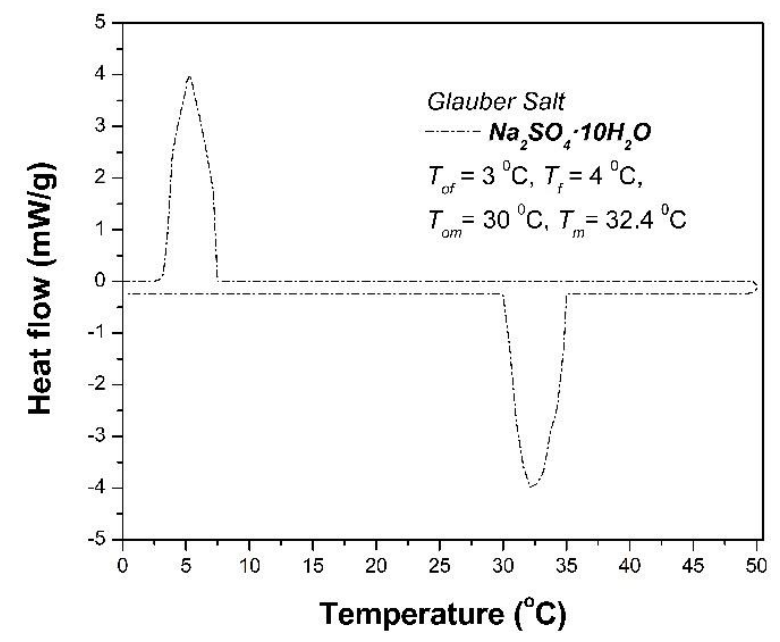

Figure 6. DSC curve of sodium sulfate and decahydrate. 
The STPV module converts the light energy into electrical energy due to the photovoltaic effect. The incident solar radiation plays a vital role in the power production of the STPV module. The solar radiation varies with respect to the geographical conditions and the seasonal variation. The experimentation was carried out during the summer season for two typical days in a location that experiences hot and humid weather. Results were plotted for the hottest day of the month and the average day of the month. In Figure 7, the incident solar radiation is shown, and it reached a maximum of $975 \mathrm{~W} / \mathrm{m}^{2}$ at 13:00 and gradually started to decrease. The maximum average solar radiation was $725 \mathrm{~W} / \mathrm{m}^{2}$.

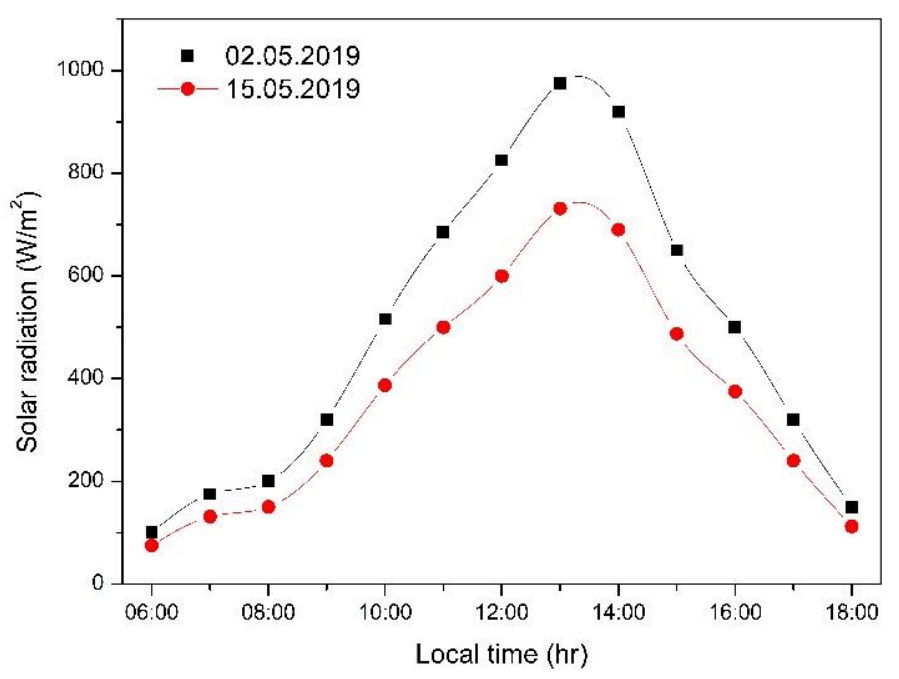

Figure 7. Hourly variation of the solar radiation at Kovilpatti during the month of May 2019.

\subsection{Electrical Performance of STPV}

The electrical performance of the STPV module is an important parameter that is to be analyzed. For analyzing the electrical performance, a variable electrical load in the form of a rheostat was considered. The voltage and current were measured by varying the load.

The output power was measured and plotted in Figure 8a. The energy conversion efficiency of the module was calculated using the output power and solar radiation of the system, which is shown in Figure $8 \mathrm{~b}$. The output power of the STPV module on the hottest day during summer is illustrated in Figure 8a. It is inferred from the graph that the output power increased from the morning and reached its maximum at 13:00 and gradually started decreasing. Due to the photons present in the solar radiation strikes on the surface of the STPV module, flow electron takes place during the bright sunshine hour. For diffused sunlight, the presence of the photons in the sunlight is less. Thus, the energy production from the module became low which is seen after 16:00. The STPV module with PCM yielded a higher output power compared to the module without PCM. STPV module without PCM yielded a maximum of $18.5 \mathrm{~W}$ at 13:00 while STPV-PCM obtained a maximum of $20.35 \mathrm{~W}$. The maximum energy conversion efficiency of the module with PCM was $20.43 \%$ while the module without PCM reached a maximum of $18.58 \%$. A similar pattern was obtained in a typical day of summer during 15 May 2019 as shown in Figure 9a,b. The module with and without PCM generated $148 \mathrm{Whr}$ and $130 \mathrm{Whr}$, respectively, for the $24 W_{P}$ module. The output power of the STPV-PCM module was increased by $12.16 \%$ due to the use of PCM. 


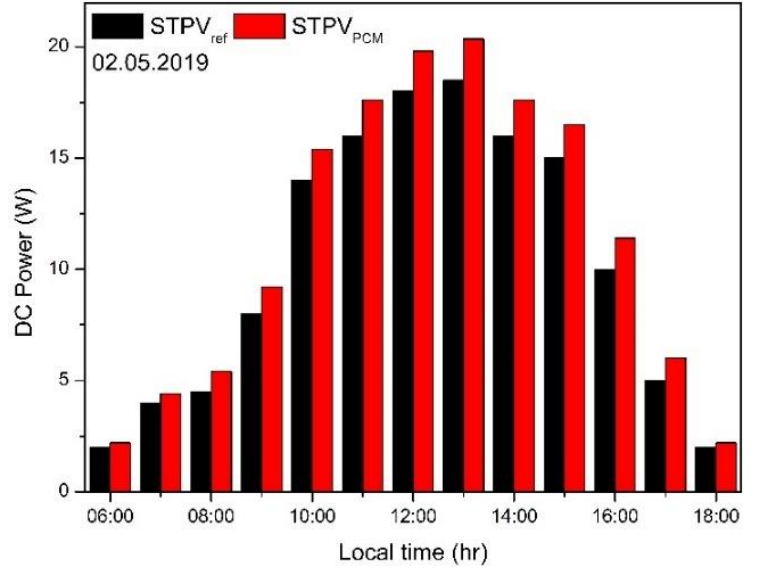

(a)

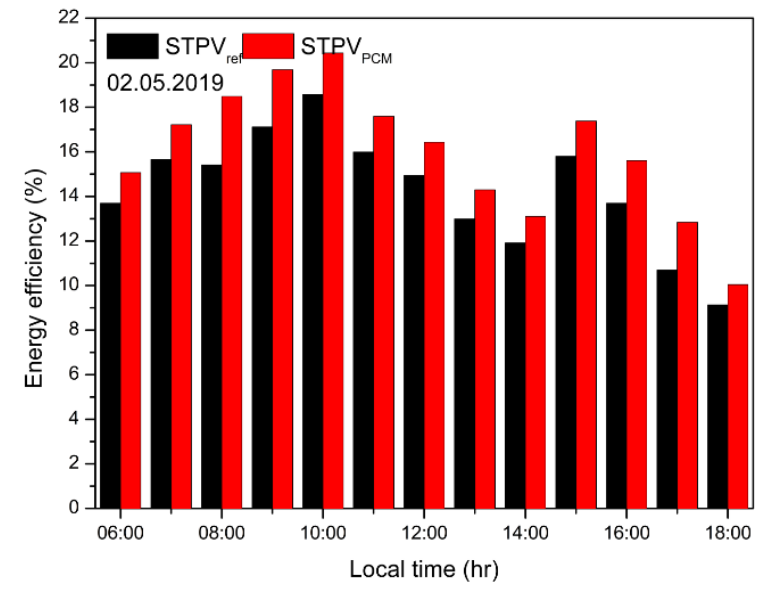

(b)

Figure 8. Hourly variation of the performance of the STPV module with and without PCM on a typical day, 2 May 2019: (a) DC output power; (b) energy conversion efficiency.

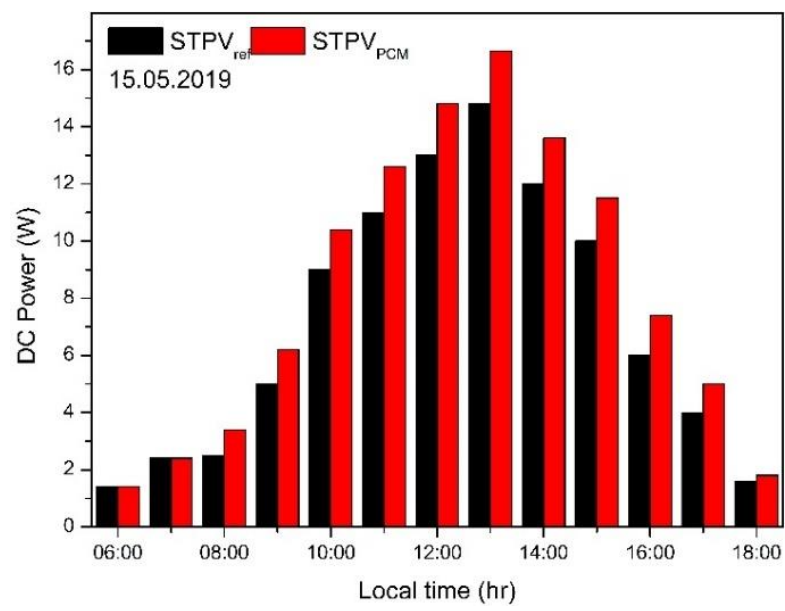

(a)

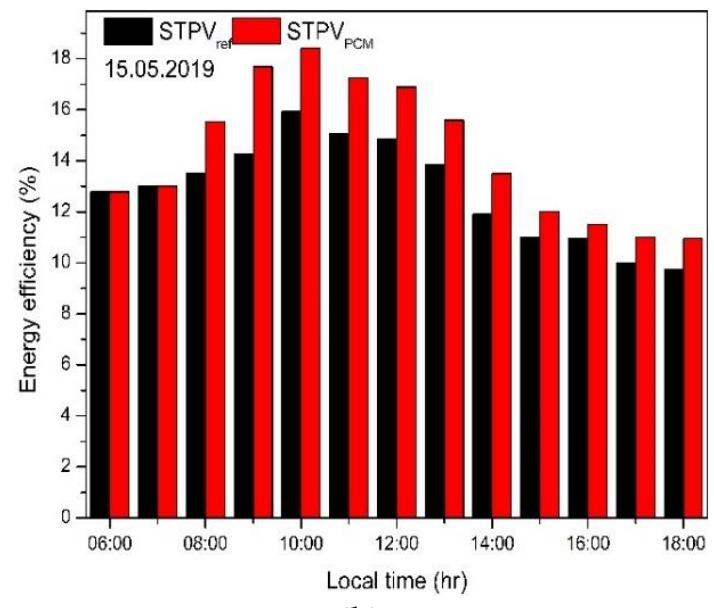

(b)

Figure 9. Hourly variation of the performance of the STPV module with and without PCM on a typical day, 15 May 2019: (a) DC output power; (b) energy conversion efficiency.

\subsection{Thermal Performance of STPV}

To enhance the thermal performance of the STPV system, PCM was incorporated. The increase in STPV surface temperature reduced the output power of the STPV module due to a rise in the internal charge carrier recombination rate of the PV cell. The flow of electrons reduced and decreased the output power. Hence, the surface temperature of the module was controlled and monitored. In Figure 10a, it is inferred that the surface temperature of the STPV module with the PCM was less than the module without PCM. The PCM absorbed the incident solar light and heat energy on the surface of the module and maintained the surface temperature of the module close to the melting temperature of the PCM. When the energy storing capacity reached the saturation state of the latent heat, the PCM started emitting energy to the atmosphere $[20,29]$. The instantaneous surface temperature was reduced to $9{ }^{\circ} \mathrm{C}$. The incorporation of the PCM has reduced the surface temperature addition, and thus indirectly improving the electrical performance of the system. In Figure 10a,b, the surface temperature of the STPV module with PCM and without PCM is plotted. The ambient temperature of the location ranged from $29^{\circ} \mathrm{C}$ to $35^{\circ} \mathrm{C}$ during the hottest day in the summer. The freezing point of the selected PCM is $4^{\circ} \mathrm{C}$. Due to the ambient temperature, active methods are required to regain the energy storage capacity of the PCM. Hence, cold water was flowed rear side of the module to solidify the PCM. The room 
temperature varied between $27^{\circ} \mathrm{C}$ to $33^{\circ} \mathrm{C}$. The maximum $\mathrm{PV}$ surface temperature reached $55^{\circ} \mathrm{C}$ without the PCM module, while PCM reached $46^{\circ} \mathrm{C}$. In the hot and humid climatic region, the room temperature was always less than the ambient temperature due to the insulation provided.

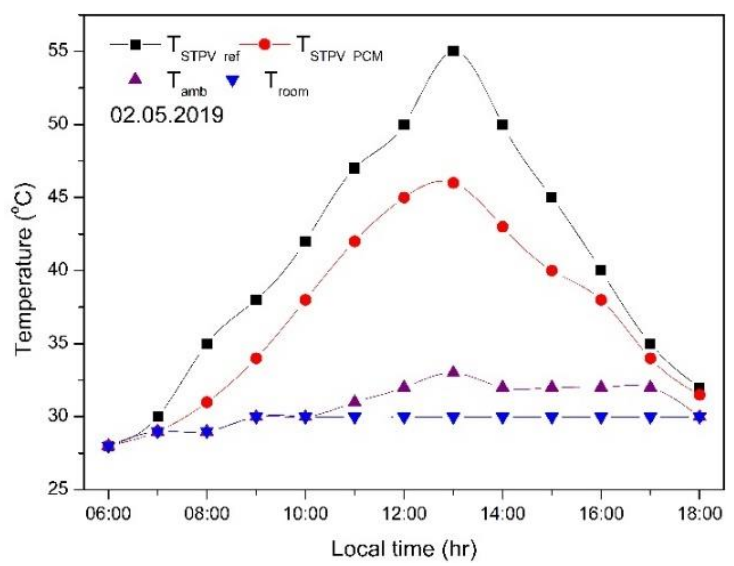

(a)

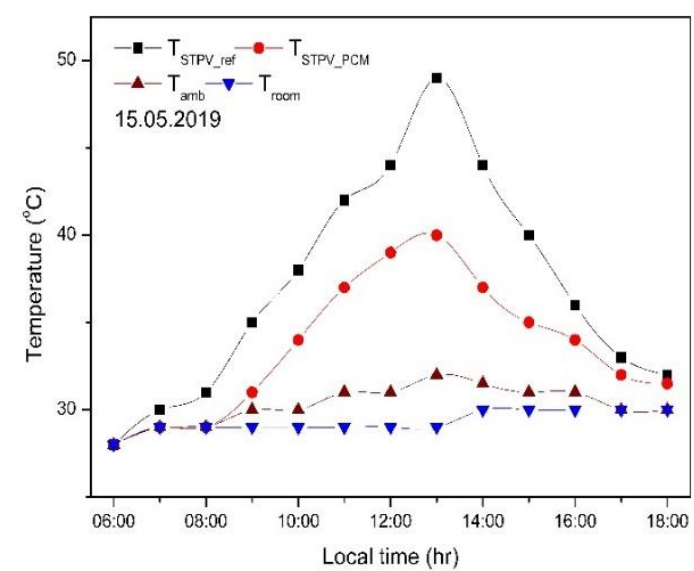

(b)

Figure 10. Hourly variation of the surface temperature of the STPV module with and without PCM on a typical day: (a) 2 May 2019; (b) 15 May 2019.

The solar heat gain of the building was obtained using the surface temperature of the window glass and the room temperature. The solar heat energy performance of the double clear glass (DCG) window, STPV window, and STPV-PCM window was compared and is shown in Figure 11. The DCG window allowed solar heat gain with a maximum of $325 \mathrm{~W}$ during noon. At the same time, STPV without PCM reached the maximum, i.e., $75 \mathrm{~W}$, while STPV with PCM obtained $70 \mathrm{~W}$. The traditional transparent DCG window allowed higher solar energy into a building's interior because of its higher transmission $(>70 \%)[34,35]$. Opaque silicon-based spaced type STPV has potential to restrict the solar energy transmission as silicon has high absorption [36,37]. Due to latent heat capacity, STPV-PCM slowed down the increment of a building's interior room temperature in a higher order compared to other two systems [38,39]. The utilization of STPV with the PCM module will reduce the cooling load of the building by minimizing the solar heat gain into the ZEB buildings.

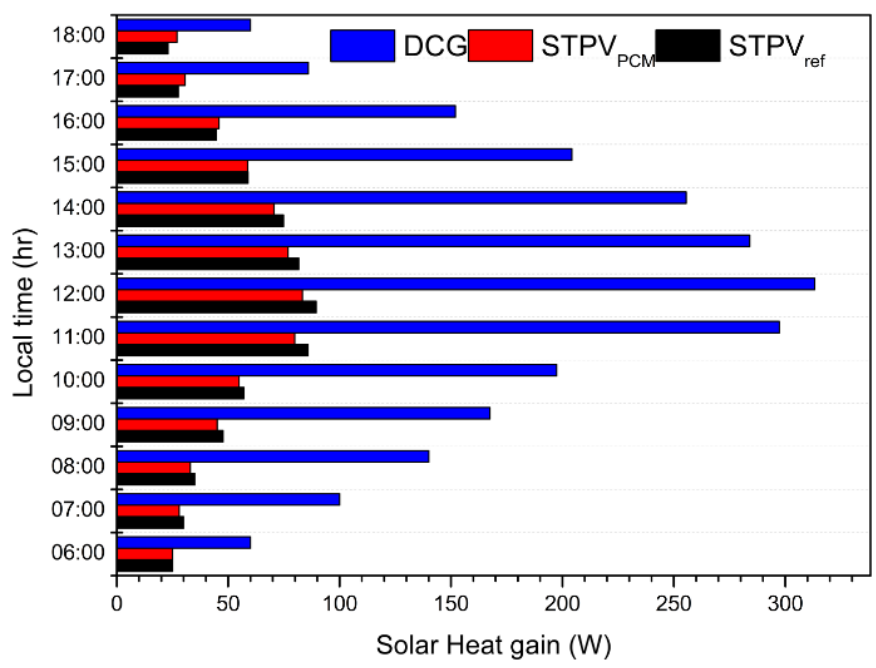

Figure 11. Hourly variation of the solar heat gain through STPV, STPV-PCM, and double clear glass (DCG) on the hottest day (2 May 2019). 


\section{Conclusions}

The main objective of the study was to enhance the performance of the STPV module. In this research, two special prototypes of the STPV modules were fabricated, and among the two, one module had the provision of incorporating PCM, and the one acted as a reference module. The experimentation was carried out during the summer season of a hot and humid southern India location. After a thorough investigation, the following conclusions were made:

- The integration of the PCM reduced the instantaneous peak PV temperature to $9{ }^{\circ} \mathrm{C}$ during summer compared to the reference STPV module;

- The conversion efficiency of the STPV-PCM was improved by $9.4 \%$ compared to the reference STPV module;

- The STPV-PCM output power production was increased by $12.16 \%$ compared to the reference STPV module;

- The instantaneous peak solar heat gain of the building through the DCG window was observed as $325 \mathrm{~W}$, while the STPV-PCM and STPV windows were $70 \mathrm{~W}$ and $75 \mathrm{~W}$, respectively.

The STPV module with Glauber salt and graphene oxide is an optimum solution to regulate the surface temperature of the STPV module and enhances the power production. In addition, it reduces the energy consumption in the ZEB buildings.

Author Contributions: Conceptualization, A.K. and M.M.A.; data curation, M.M.A. and M.K.P.; formal analysis, A.K. and N.M.K.; funding acquisition, A.G.; investigation, M.K.P.; methodology, A.K.; resources, A.K. and A.G.; supervision, S.S.C. and A.K.; validation, N.M.K.; visualization, A.K. and N.M.K.; writing-original draft, A.K. and M.M.A.; writing-review \& editing, N.M.K., S.S.C., and A.G. All authors have read and agreed to the published version of the manuscript.

Funding: This research received no external funding.

Acknowledgments: We would like to thank to the K. Kalidasa Murugavel, National Engineering college, Kovilpatti-628503, Tamilnadu, India for his support to complete this project.

Conflicts of Interest: The authors declare no conflict of interest.

\section{References}

1. Kumar, N.M.; Yadav, S.K.; Chopra, S.S.; Bajpai, U.; Gupta, R.P.; Padmanaban, S.; Blaabjerg, F. Operational performance of on-grid solar photovoltaic system integrated into pre-fabricated portable cabin buildings in warm and temperate climates. Energy Sustain. Dev. 2020, 57, 109-118. [CrossRef]

2. Reddy, K.P.; Gupta, M.V.N.; Nundy, S.; Karthick, A.; Ghosh, A. Status of BIPV and BAPV System for Less Energy-Hungry Building in India-A Review. Appl. Sci. 2020, 10, 2337. [CrossRef]

3. Karthick, A.; Murugavel, K.K.; Kalaivani, L.; Saravana Babu, U. Performance study of building integrated photovoltaic modules. Adv. Build. Energy Res. 2018, 12, 178-194. [CrossRef]

4. Naveen Chakkaravarthy, A.; Subathra, M.S.P.; Jerin Pradeep, P.; Manoj Kumar, N. Solar irradiance forecasting and energy optimization for achieving nearly net-zero energy building. J. Renew. Sustain. Energy 2018, 10, 035103. [CrossRef]

5. Kumar, N.M.; Sudhakar, K.; Samykano, M. Performance comparison of BAPV and BIPV systems with c-Si, CIS and CdTe photovoltaic technologies under tropical weather conditions. Case Stud. Therm. Eng. 2019, 13, 100374. [CrossRef]

6. Alrashidi, H.; Ghosh, A.; Issa, W.; Sellami, N.; Mallick, T.K.; Sundaram, S. Thermal performance of semi-transparent CdTe BIPV window at temperate climate. Sol. Energy 2020, 195, 536-543. [CrossRef]

7. Ghosh, A.; Bhandari, S.; Sundaram, S.; Mallick, T.K. Carbon counter electrode mesoscopic ambient processed \& characterised Perovskite for adaptive BIPV fenestration. Renew. Energy 2020, 145, 2151-2158.

8. Roy, A.; Ghosh, A.; Bhandari, S.; Selvaraj, P.; Mallick, T.K.; Sundaram, S. Colour Comfort Evaluation of Dye Sensitized Solar Cells Glazing after Two Years of Ambient Exposure. J. Phys. Chem. C 2019, 123, 23834-23837. [CrossRef]

9. Selvaraj, P.; Ghosh, A.; Mallick, T.K.; Sundaram, S. Investigation of semi- transparent dye-sensitized solar cells for fenestration integration. Renew. Energy 2019, 141, 516-525. [CrossRef] 
10. Ghosh, A.; Sundaram, S.; Mallick, T.K. Investigation of thermal and electrical performances of a combined semi-transparent PV-vacuum glazing. Appl. Energy 2018, 228, 1591-1600. [CrossRef]

11. Ghosh, A.; Selvaraj, P.; Sundaram, S.; Mallick, T.K. The colour rendering index and correlated colour temperature of dye-sensitized solar cell for adaptive glazing application. Solar Energy 2018, 163, 537-544. [CrossRef]

12. Karthick, A.; Murugavel, K.K.; Prabhakaran, D.S.R. Energy analysis of building integrated photovoltaic modules. In Proceedings of the 2017 International conference on power and embedded drive control (ICPEDC 2017), Chennai, India, 16-18 March 2017; pp. 307-311.

13. Ramanan, P.; Murugavel, K.K.; Karthick, A. Performance analysis and energy metrics of grid-connected photovoltaic systems. Energy Sustain. Dev. 2019, 52, 104-115.

14. Karthick, A.; Murugavel, K.K.; Sudalaiyandi, K.; Manokar, A.M. Building integrated photovoltaic modules and the integration of phase change materials for equatorial applications. Build. Serv. Eng. Res. Technol. 2019. [CrossRef]

15. Alrashidi, H.; Issa, W.; Sellami, N.; Ghosh, A.; Mallick, T.K.; Sundaram, S. Performance assessment of cadmium telluride-based semi-transparent glazing for power saving in façade buildings. Energy Build. 2019, 109585. [CrossRef]

16. Karthick, A.; Murugavel, K.K.; Kalaivani, L. Performance analysis of semi-transparent photovoltaic module for skylights. Energy 2018, 162, 798-812. [CrossRef]

17. Ramanan, P.; Murugavel, K.K.; Karthick, A.; Sudhakar, K. Performance Evaluation of Building-Integrated Photovoltaic Systems for Residential Buildings in Southern India. Build. Serv. Eng. Res. Technol. 2020, 41, 492-506. [CrossRef]

18. Sardarabadi, M.; Passandideh-Fard, M.; Maghrebi, M.J.; Ghazikhani, M. Experimental study of using both $\mathrm{ZnO} /$ water nanofluid and phase change material (PCM) in photovoltaic thermal systems. Sol. Energy Mater. Sol. Cells 2017, 161, 62-69. [CrossRef]

19. Khanna, S.; Reddy, K.S.; Mallick, T.K. Optimization of solar photovoltaic system integrated with phase change material. Sol. Energy 2018, 163, 591-599. [CrossRef]

20. Karthick, A.; Murugavel, K.K.; Ramanan, P. Performance enhancement of a building-integrated photovoltaic module using phase change material. Energy 2018, 142, 803-812. [CrossRef]

21. Modjinou, M.; Ji, J.; Yuan, W.; Zhou, F.; Holliday, S.; Waqas, A.; Zhao, X. Performance comparison of encapsulated PCM PV/T, microchannel heat pipe PV/T and conventional PV/T systems. Energy 2019, 166, 1249-1266. [CrossRef]

22. Al-Waeli, A.H.; Sopian, K.; Chaichan, M.T.; Kazem, H.A.; Ibrahim, A.; Mat, S.; Ruslan, M.H. Evaluation of the nanofluid and nano-PCM based photovoltaic thermal (PVT) system: An experimental study. Energy Convers. Manag. 2017, 151, 693-708. [CrossRef]

23. Abdelrazik, A.S.; Al-Sulaiman, F.A.; Saidur, R. Numerical investigation of the effects of the nano-enhanced phase change materials on the thermal and electrical performance of hybrid PV/thermal systems. Energy Convers. Manag. 2020, 205, 112449. [CrossRef]

24. Mahmoudi, T.; Wang, Y.; Hahn, Y.B. Graphene and its derivatives for solar cells application. Nano Energy 2018, 47, 51-65. [CrossRef]

25. Rathod, P.B.; Nemade, K.R.; Waghuley, S.A. Improvement in photovoltaic performance of $\mathrm{TiO}_{2}$ nanoparticles by decoration of graphene nanosheets with spherical $\mathrm{TiO}_{2}$ nanoparticles. Mater. Lett. 2016, 169, 118-121. [CrossRef]

26. Karthick, A.; Ramanan, P.; Ghosh, A.; Stalin, B.; Kumar, R.V.; Baranilingesan, I. Performance enhancement of copper indium diselenide photovoltaic module using inorganic phase change material. Asia-Pac J Chem Eng. 2020, e2480. [CrossRef]

27. Singh, P.; Khanna, S.; Newar, S.; Sharma, V.; Reddy, K.S.; Mallick, T.K.; Khusainov, R. Solar Photovoltaic Panels with Finned Phase Change Material Heat Sinks. Energies 2020, 13, 2558. [CrossRef]

28. Hasan, A.; McCormack, S.J.; Huang, M.J.; Norton, B. Energy and cost saving of a photovoltaic-phase change materials (PV-PCM) system through temperature regulation and performance enhancement of photovoltaics. Energies 2014, 7, 1318-1331. [CrossRef]

29. Karthick, A.; Murugavel, K.K.; Ghosh, A.; Sudhakar, K.; Ramanan, P. Investigation of a binary eutectic mixture of phase change material for building integrated photovoltaic (BIPV) system. Sol. Energy Mater. Sol. Cells 2020, 207, 110360. [CrossRef] 
30. Kumar, P.M.; Mylsamy, K. Experimental investigation of solar water heater integrated with a nanocomposite phase change material. J. Therm. Anal. Calorim. 2019, 136, 121-132. [CrossRef]

31. Kumar, P.M.; Mylsamy, K.; Saravanakumar, P.T. Experimental investigations on thermal properties of nano-SiO 2 /paraffin phase change material (PCM) for solar thermal energy storage applications. Energy Sources Part A Recovery Util. Environ. Eff. 2019, 1-14. [CrossRef]

32. Kumar, P.M.; Anandkumar, R.; Sudarvizhi, D.; Prakash, K.B.; Mylsamy, K. Experimental investigations on thermal management and performance improvement of solar PV panel using a phase change material. AIPC 2019, 2128, 020023.

33. Li, W.; Dong, Y.; Zhang, X.; Liu, X. Preparation and performance analysis of graphite additive/paraffin composite phase change materials. Processes 2019, 7, 447. [CrossRef]

34. Ghosh, A.; Norton, B.; Duffy, A. Measured thermal \& daylight performance of an evacuated glazing using an outdoor test cell. Appl. Energy 2016, 177, 196-203.

35. Ghosh, A.; Norton, B.; Duffy, A. Effect of sky clearness index on transmission of evacuated (vacuum) glazing. Renew. Energy 2017, 105, 160-166. [CrossRef]

36. Ghosh, A.; Sundaram, S.; Mallick, T.K. Colour properties and glazing factors evaluation of multicrystalline based semi-transparent Photovoltaic-vacuum glazing for BIPV application. Renew. Energy 2019, 131, 730-736. [CrossRef]

37. Peng, J.; Curcij, D.C.; Thanachareonkit, A.; Lee, E.S.; Goudey, H.; Selkowitz, S.E. Study on the overall energy performance of a novel c-Si based semitransparent solar photovoltaic window. Appl. Energy 2019, 242, 854-872. [CrossRef]

38. Yang, L.; Huang, J.; Zhou, F. Thermophysical properties and applications of nano-enhanced PCMs: An update review. Energy Convers. Manag. 2020, 214, 112876. [CrossRef]

39. Ghosh, A.; Norton, B. Advances in switchable and highly insulating autonomous (self-powered) glazing systems for adaptive low energy buildings. Renew. Energy 2018, 126, 1003-1031. [CrossRef]

(C) 2020 by the authors. Licensee MDPI, Basel, Switzerland. This article is an open access article distributed under the terms and conditions of the Creative Commons Attribution (CC BY) license (http://creativecommons.org/licenses/by/4.0/). 